
\title{
$\angle S$ Research Suare \\ Egg production performance of three strains of laying hens kept in floor pens
}

Mebratu Yigzaw ( $\square$ yigzawmebratu62@gmail.com )

Injibara university https://orcid.org/0000-0002-4880-701X

Solomon Demeke

Jimma University College of Agriculture and Veterinary Medicine

Wasihun Hassen

Jimma University College of Agriculture and Veterinary Medicine

\section{Research Article}

Keywords: Egg production, Breed, Exotic, Survival, Ethiopia

Posted Date: November 9th, 2021

DOI: https://doi.org/10.21203/rs.3.rs-1026950/v1

License: (c) (i) This work is licensed under a Creative Commons Attribution 4.0 International License.

Read Full License 


\section{Abstract}

Genetic limitation is one of the major bottle necks for the development of the poultry production and the expansion of the commercial poultry production is limited by inadequate supply of high performing chicken breeds locally in Ethiopia. Research system is currently attempting to alleviate this problem by introducing improved poultry breeds that can adapt and perform in Ethiopia. This experiment was carried out to study the on station egg production performance of Lohman Brown, Novo Brown and Dominant Sussex breeds under the objective condition of Jimma. One hundred fifty of each of Dominant Sussex, Lohman Brown and Novo Brown breed of layers obtained from Debre Zeit Research Station was placed at Jucavm layer house on standard commercial layers' ration in completely randomized design with three replicates. Finally, all the data collected on performance of the experimental breeds of chickens were subjected to statistical analysis. There was no significant difference $(P<0.05)$ between the three breeds tested in age at the first egg, even if Lohman Brown tended to lay comparatively earlier (137 days). The hen day egg production rate and egg weight of Dominant Sussex was better than other two breeds. In summary, the results of this experiment indicated that the three breed of chicken have well performed (except the adaptive potential of Dominant Sussex chickens) under Jimma condition in most of the economically important production traits studied. However, comparative evaluation of the egg quality and reproductive performance of the three breeds seems to be the future direction of research under objective condition of Jimma.

\section{Introduction}

Poultry production has an important economic, social and cultural benefit and plays a significant role in the provision of animal protein and family income in the developing countries. The contribution of poultry to the total global animal protein production is assumed to reach about $40 \%$ by the year 2020 , the major increase being in the developing world (Delgado et al., 2001). In sub Saharan Africa, $85 \%$ of the rural population keeps chicken as a source of affordable animal protein and household income (Aklilu et al., 2007). Poultry is also an employment opportunity for the youth, elders and women in the urban and periurban areas and Ethiopia is not exception to this situation. Recent estimates put the Ethiopian poultry population at about 60 million out of which $90.85,4.76$, and $4.39 \%$ is reported to be indigenous, hybrid and exotic chickens respectively (CSA, 2016/17). The poultry sub-sector in Ethiopia could be characterized into three major production systems based on some selected parameters such as breed, flock size, management practices, technological input and level of bio-security exercised (Bush, 2006). The three production systems are backyard (traditional) poultry production, small-scale modern poultry and large scale commercial poultry. Each of these production systems sustainably coexist and contribute to the socio-economic status of different target societies (Tadelle et al., 2003c).

The backyard (traditional) poultry production system is entirely dominated by indigenous chickens and characterized by low input - output and periodic devastation of the flocks due to disease outbreaks (Tadelle et al., 2003b). The indigenous chickens are low in productivity owing to their low egg production performance, slow growth rate, late sexual maturity, pronounced broodiness and high chick mortality. 
Poor management practice and veterinary services also contribute to the low productivity of the indigenous chickens. It has been seen that improvement of basic husbandry practice and health care improve the performance of indigenous chicken, but not to an economically acceptable level (Teketel, 1986; Abebe, 1992). Local chickens are considered to be disease resistant and adapted to their scavenging environmental conditions. However, local chickens kept under the intensive system of management (in confinement) are inferior to exotic stock in health status and characterized by a lack of interest in their environment, wing droppings, huddling at the corner, leg weakness and cannibalism. They are also slow in rate of feathering and exhibit recurrent outbreaks of disease (Demeke, 2004). The percentage mortality from hatching to maturity was significantly higher for local chickens kept under an intensive management system (24\%) compared to the Leghorns (7.3\%) kept under similar condition. Higher mortalities and morbidities have been reported among local birds than White Leghorns when raised under intensive management conditions in Awassa (Teketel Forsido, 1986) and Debre Zeit (Abebe Hailu, 1987).

In Ethiopia, the importation of exotic breeds of chicken goes back to the early 1950s (Solomon, 2008). About $99 \%$ of the Ethiopian poultry population consists of indigenous chickens, while the remaining $1 \%$ consists of imported exotic breeds of chickens during the 1970s and 1980s (Alamargot, 1987). There has been an increase in the number of exotic breeds of chickens and at present it is estimated that these make up about $4.39 \%$ of the national poultry population CSA, 2016/17). But, the contribution of exotic poultry to the Ethiopian economy is significantly lower than that of other African countries and all the available evidence indicates that all the imported breeds of chickens performed well under the intensive management system (Yami and Dessie, 1997). In addition, with an annual human population growth rate of $2.4 \%$, the present above 80 million Ethiopia's human population will increase to about 149.3 million by the year 2040 (FAO, 2005). Thus, the demand for animal products is expected to increase substantially. Therefore, to meet the ever-increasing demand for meat and eggs, increase the contribution of exotic chicken to Ethiopian economy and expansion of commercial poultry production introduction of superior/exotic breed has been proposed as one of the plausible option. As a result, currently the Ethiopian Institute of Agricultural Research introduced Lohman Brown, Novo Brown and Dominant Sussex d104 Final hybrid layers. The Lohman Brown is egg type breed of hybrid origin, selectively bred from New Hampshire's and other brown egg laying breeds of chickens (Felt well, 2011). They start lying at an age of 18 weeks and reported to lay up to 300 brown eggs per year. Novo Brown starts lying at an age of about 20 - 24 weeks. Under commercial conditions, productivity of Novo Brown is reported to be around 330 eggs per year. Dominant Sussex D 104 is a result of crossing paternal Sussex stock with slow feathering maternal stock and an attractively colored layer for small scale and free-range production conditions. This bird is adapted for sub-optimal and harsh production conditions of free-range system and small scale farming. This being the case, the major objectives of this research project was on-station evaluation of Dominant Sussex d104, Lohman Brown and Novo Brown Final hybrid layers in Jimma with the following specific objectives:

- Comparative on-station evaluation of the egg production measurement and the survival rates of Dominant Sussex d104, Lohman Brown and Novo Brown Final hybrid layers in Jimma. 


\section{Materials And Methods \\ 2.1. Description of the Experimental Site}

This experiment was conducted at Jimma University College of Agriculture and Veterinary Medicine (JUCAVM), located at $357 \mathrm{~km}$ Southwest of Addis Ababa and at about $7^{0} 33^{\prime} \mathrm{N}$ latitude and $36^{\circ} 57^{\prime} \mathrm{E}$ longitudes. The altitude of JUCAVM is 1700 meters above sea level. The mean maximum and minimum temperature of the study area is $26.8^{\circ} \mathrm{C}$ and $11.4^{\circ} \mathrm{C}$, respectively and the mean maximum and minimum relative humidity is $91.4 \%$ and $39.92 \%$ respectively. The mean annual rainfall of the area is $1500 \mathrm{~mm}$ (BPEDORS, 2000).

\subsection{Management of Experimental Chickens}

A total of 500 pullets of the three breeds were housed at JUCAVM chicken house. One hundred fifty pullets of each of Dominant Sussex d104, Lohman Brown and Novo Brown breeds were randomly selected from the total of 500 in each case. The selected pullets of each breed were placed in separate pens and placed on standard commercial layer ration for 7 days. At the end of the 7 days, each group (breed) of 150 chicks was further sub-divided into three groups, each with 50 pullet of equal mean group weight (total of 9 groups each with 50 pullets). Finally, each group of 50 experimental pullets was randomly assigned to the experimental pens in completely randomized design with 3 replicates (as shown in Table1).

All the groups of the experimental layers were placed standard layer ration at age of 20 weeks. Selected males of each breed were mixed with their respective females at the ratio of 1:10. Known amount feed was offered 3 times a day the orts were collected and weighed on the next morning at 2:00pm. Adequate clean water was made available all the times. The experimental pens were cleaned and disinfected before the arrival of the chicken and thoroughly cleaned every time during the study period. Sick birds were isolated, and when dead post mortem examination was carried out to determine the cause of mortality. Dead birds were disposed of properly. Whenever the litter got wet, it was replaced with dry and clean one to make sure the pen is clean at all times. Body weight was measured every week. Mortality and disease conditions were recorded as occurred.

Table 1

Treatment allocation to the experimental chickens in completely randomized design

\begin{tabular}{|llll|}
\hline Treatment & Replication & No. Chickens/Replication & No. Chickens/Treatment \\
\hline Lohman Brown & 3 & 50 & 150 \\
\hline Novo Brown & 3 & 50 & 150 \\
\hline Dominant Sussex & 3 & 50 & 150 \\
\hline Total & 9 & 150 & 450 \\
\hline
\end{tabular}




\subsection{Rate of Production}

\subsubsection{Egg production measurement}

The production traits used to differentiate the experimental breeds was including egg weight, egg mass and egg production rate per day. The egg was measured using sensitive balance by collecting eggs daily and weighted in group immediately after collection for each replication and average egg weight was computed by dividing the total egg weight to the total number of eggs. After mean weight has been determined, the following formula was employed to calculate the egg mass per pen on daily bases developed by (North, 1984).

$M=P X W$. Where, $M=$ av. egg mass / hen/day

$\mathrm{P}=\%$ hen- day egg production

$\mathrm{W}=$ av. egg weight in gram

Feed intake was measured by subtracting the amount refused from the amount offered on DM basis. Body weight was taken on weekly basis. The mean dry matter conversion ratio was determined as the ratio of gram egg mass from gram dry matter consumed (Ensminger et al., 1990).

\section{$\mathrm{FCR}=$ Daily feed consumed $(\mathrm{g})$}

Daily egg mass (g)

Eggs were collected daily from each pen. The sum of the collections was recorded as egg production for that day. The number of birds alive per replicate on each day was also recorded. Rate of lay for each replicate was expressed as the average percentage hen-day egg production following the method developed by Hunton (1995) as follow:

$\%$ Hen - day egg production $=$ Number of eggs collected per day $\times 100$

Number of hens present on that day

\subsection{Statistical Analysis}

The data collected were analyzed using the procedures suggested by Gomez and Gomez (1984) using SPSS (Statistical Package for Social Science) software version 20. When the analysis of variance indicates the existence of significant difference among the treatment means at $5 \%$ level of significance for the quantitative data, Turkey's Honestly Significant Difference (HSD) test was employed to test and locate the treatment means that are significantly differed from the rest. The following model suggested Montgomery, (2001) was used. 
$Y i j=\mu+T i+e i j$, Where,

Yij $=$ is the overall observation (FCR, feed intake, body weight....)

$\mu=$ population mean

$\mathrm{Ti}=$ effect of the ith breed $(\mathrm{i}=1,2,3)$

Eij $=$ Random error

\section{Result And Discussion \\ 3.1. Egg production}

\subsubsection{Egg weight and Rate of egg production}

There was significant difference between the three breeds in mean egg weight $(P<0.05)$. The mean egg weight of Novo Brown and Lohman Brown was 57.1 and $57.3 \mathrm{~g}$ respectively and Dominant Sussex had significantly larger $(P<0.05)$ mean egg weight $(59.4 \mathrm{~g})$ than the others, which may arise from the breed difference. There was no significant difference between the eggs of Novo Brown and Lohman Brown in mean egg weight $(P<0.05)$. Higher weight of egg from commercial breed is not a surprise since such breed submitted to important breeding pressure for egg weight improvement (Hocking et al., 2003). Mean egg weight of 59 and $58 \mathrm{~g}$ was reported from Koekoek hens in northern Tigray (Gebreselassie et al., 2015) and in south Africa (Grobbelaar et al., 2010), the values of which were comparable to the mean egg weight range (57-59.4 g) obtained from the current study. Singh et al. (2009) also reported mean egg weight of 59.4 and $57.9 \mathrm{~g}$ at an age 30 weeks from Lohman Brown and Lohman White strains using floor production system, respectively in Canada. According to Silversides and Scott, (2001), comparable mean egg weight 58.5 and $55.9 \mathrm{~g}$ was recorded from Isa Brown and Isa White respectively. Tadesse et al. (2012) reported mean egg weight of $48.8,58.75$ and $60.27 \mathrm{~g}$ for PK, IB and BB kept under village condition in East Shewa respectively. The average egg weight recorded for IB and BB under village/scavenging condition was $52.24 \mathrm{~g}$, the value of which was lower than that obtained in the current study (Tulin and Ahmet, 2009). The difference in size may be due to different management, age of production, level of egg production and different agro-ecological conditions among different studies.

The rate of egg production of the experimental chickens is shown in Table 2. Novo Brown and Dominant Sussex breeds had significantly higher $(\mathrm{P}<0.05)$ rate of egg production than Lohman Brown as measured by percent hen-day egg production (Table 2), this difference could be attributed to their better genetic potential for higher egg production. The egg production performance of Lohman Brown and Lohman Silver was reported to be $80 \%$ in Nigeria under intensive production system, the value of which was higher than that (63-68\%) recorded from the current study (Motiang, 2013). Similarly, the egg production performance of Lohman brown was lower than (80\%) lohman company recommendation under conditions of intensive-industrial farm type, in batteries, ensuring an optimized management,(Lohmann 
brown, 2000). The results obtained have shown a diminution by $14.5 \%$ in the productive level, because of the used technology which keeps the poultry movement and increase egg production, and also the feed shortage occurred (2-3 week) during this experiment. Slightly lower Performance rate ranging between 57$64 \%$ was reported from Potchefstroom Koekoek kept under on station at Debrezeit Agricultural Research Center (DZARC Annual Report, 2012). Mean daily egg production ranging between 0.63 and 0.68 eggs/hen chicken was recorded from the current study, the value of which was higher than that of Tadesse, (2012) who reported mean daily egg production of 0.51 eggs/hen was obtained from Potchefstroom Koekoek in East Showa Zone, Lume district under farmer's management condition as reported by Kasa Biratu and Saba Haile, (2016). Kasa Biratu and Saba Haile, (2016) also reported higher Mean daily egg production of 0.76 and $0.73 \mathrm{egg} / \mathrm{hen}$ from Isa Brown and Bovan Brown kept in East Shewa Zone respectively. The results of the rate of egg production of the current study was higher to that of Grobbelaar et al. (2010), who reported mean daily egg production of $0.54 \mathrm{egg} / \mathrm{hen}$ from Koekoek breed of chickens, but comparable than that reported by Gebreselassie et al., (2015), who reported0.66eggs/day from Koekoek breed of chicken kept under farmer condition in Tigray. The low performance of the experimental layers of the current study was due to the occurred shortage of commercial layers ration for 2-3 weeks during the study, since egg production performance is linearly related to the levels of feed offered (Fig. 1). Likewise, egg production can be affected by breed, feed consumption (quality and quantity), water intake, intensity and duration of light received, parasite infestation, diseases, management and environmental factors (Jacob et. al., 1998).

\subsubsection{Feed intake and body weight gain}

There was no significant difference $(P>0.05)$ between the three breeds in body weight gain during laying period. Lohman Brown chickens consumed significantly higher feed $(133.0 \mathrm{~g} / \mathrm{h} / \mathrm{d})$ than the others $(P<$ $0.05)$, possibly because of genetic differences in physical activity/physical condition, basal metabolic rate and body temperature (Luiting, 1990). This is also higher from the Lohmann company recommendation $(110 \mathrm{~g} / \mathrm{h} / \mathrm{d})$ under cage house production system (Lohmann Brown, 2000), which may be due to difference in housing system. Lohman Brown chickens had also significantly higher FCR value (3.7) than the others. Relatively lower mean daily feed intake (93.8g) and FCR of 2.39 was reported by Singh et al. (2009) from Lohman White layers. Relatively higher feed conversion value of 6.8 and 8.7 was also recorded from Fayoumi and Desi kept under intensive production system in Pakistan, this might be attributed to the differences in genotype and environments used. Feed conversion efficiency of 5.02, the value of which is lower to that of all breeds in the current study was reported from Desi by Khawaja et al. (2012). The same author reported feed intake of $112 \mathrm{~g} / \mathrm{h} / \mathrm{d}$ from Desi values of which were similar to that recorded from Dominant Sussex and Novo Brown breeds of chickens in the current study. Higher feed intake ( $149 \mathrm{~g} /$ day/hen), but slightly lower FCR value (2.8-3) also reported from Lohman Brown and Lohman Silver under intensive management condition in Nigeria, Moting, (2013).

\subsubsection{Egg mass and Mortality}

As shown in Table 2, there was significant difference between the three breeds in egg mass production ( $P$ $<0.05$ ). Dominant Sussex breeds had significantly higher egg mass production (40.5) than Lohman 
Brown breeds whose average egg mass production was $29.0(P<0.05)$, which could be due to their higher egg number and egg weight recorded from Dominant Sussex layers. The egg mass production of Novo Brown breeds is intermediate between the Dominant Sussex and the Lohman Brown breeds, without showing significant difference with both $(P<0.05)$. In contrast, lower value was recorded in Islamabad Pakistan from Rhode Island Red (23.3g/day/bird), Desi (12.88) and Fayumi (15.6) hens kept under intensive production system (Khawaja et al., 2012). Dominant Sussex experimental layers tended to show higher mortality than the others (Table 2). Comparable rate of mortality was reported by Singh et al., (2009), from Lohman Brown (1.67) and Lohman White (3.33). But, higher result of mortality (5-10\%) during egg production was recorded from Lohman Brown and Lohman Silver in Nigeria, under on station production system, Moting (2013).

Table 2

Egg production performance of the experimental layers

\begin{tabular}{|lllll|}
\hline Parameter & $\begin{array}{l}\text { Novo } \\
\text { Brown } \\
(\text { Mean } \pm \text { SE) }\end{array}$ & $\begin{array}{l}\text { Lohman Brown } \\
\text { (Mean } \pm \text { SE) }\end{array}$ & $\begin{array}{l}\text { Dominant Sussex } \\
\text { (Mean } \pm \text { SE) }\end{array}$ & Sig. \\
\hline Egg weight(g) & $57.1^{\mathrm{b}} \pm 0.7$ & $57.3^{\mathrm{b}} \pm 0.61$ & $59.4^{\mathrm{a}} \pm 0.43$ & .01 \\
\hline Egg mass (g/day/bird) & $38.1^{\mathrm{ab}} \pm 0.91$ & $35.9^{\mathrm{b}} \pm 0.35$ & $40.5^{\mathrm{a}} \pm 0.52$ & .013 \\
\hline Hen day egg production \% & $66.5^{\mathrm{a}} \pm 1.47$ & $62.2^{\mathrm{b}} \pm 1.41$ & $68.1^{\mathrm{a}} \pm 0.45$ & .002 \\
\hline Body weight gain(g/h/day) & $3.96^{\mathrm{a}} \pm 0.85$ & $3.37^{\mathrm{a}} \pm 0.93$ & $3.71^{\mathrm{a}} \pm 0.66$ & .696 \\
\hline Feed intake(g/h) & $112.4^{\mathrm{b}} \pm 0.8$ & $133^{\mathrm{a}} \pm 4.56$ & $119.3^{\mathrm{b}} \pm 4.88$ & .026 \\
\hline $\begin{array}{l}\text { Feed conversion efficiency (g } \\
\text { feed: g egg mass) }\end{array}$ & $2.93^{\mathrm{b}} \pm 0.14$ & $3.7^{\mathrm{a}} \pm 0.27$ & $2.93^{\mathrm{b}} \pm 0.18$ & .013 \\
\hline Mortality & $2.63^{\mathrm{b}} \pm 0.50$ & $2.83^{\mathrm{b}} \pm 0.16$ & $3.58^{\mathrm{a}} \pm 0.16$ & \\
\hline a, b, c: Means with different superscripts in a row are significantly different at $\mathrm{P}<0.05$. & \\
\hline
\end{tabular}

\section{Conclusion And Recommendation}

In Ethiopia, the expansion of commercial poultry production is limited by inadequate supply of high performing breeds of chicken. This situation warrants the identification, introduction and evaluation of improved breeds of chicken that could adapt and perform under the current Ethiopian situation. Research system is currently attempting to alleviate this problem by identifying, introducing and evaluating improved poultry breeds that can adapt and perform under Ethiopian situation. This experiment was carried out to study the on station egg production performance of Lohman Brown, Novo Brown and Dominant Sussex breeds of exotic chicken under the objective condition of Jimma. Novo Brown breed was characterized by better feed conversion efficiency and egg production. Dominant Sussex chicks were 
also performed better in rate of egg production, egg weight and egg mass measurement. But, it was performed poor in rate of survival than both Lohman Brown and Nova Brown chicks. Lohman Brown was characterized by relatively early maturity. The following recommendations were suggested based on the results of the current study.

- Novo Brown and Lohman Brown along with other basic input setup could be included into technical poultry extension packages.

- Further on station evaluation on egg quality and reproductive performance of the three breeds of chickens in different areas should be done.

\section{Declarations}

\section{Acknowledgements}

Authors gratefully acknowledge the support and kind commitment of data collectors.

\section{Availability of data and materials}

The data used in this study are available from the corresponding author upon reasonable request.

\section{Disclosure statement}

Authors declare no competing interest.

\section{Funding}

No funding was used for this study.

\section{Ethical declaration}

This study involved a data sheet-based body weight measurement study of chickens. The study protocol was assessed and approved by Jimma University, College of Agriculture and Veterinary Medicine research and extension office. Body weight measurement was carried out by Animal science expert adhering to the regulations and guidelines on animal husbandry and welfare.

\section{References}

1. Abebe, H., 1992. Terminal report on the comparative evaluation of native chicken in the Hararge Administrative region and their crosses with the single comb white Leghorn. Memeographed report. Alemaya University of Agriculture, pp.22-27.

2. Abebe $H, 1987$. Annual progress report of the poultry section of the Debre Zeit agricultural research center. Mimeographed report. Debre Zeit Agricultural Research Center. 
3. Aklilu, H.A., Almekinders, C.J.M., Udo, H.M.J. and Van der Zijpp, A.J., 2007. Village poultry consumption and marketing in relation to gender, religious festivals and market access. Tropical Animal Health and Production, 39(3), pp.165-177.

4. Alamargot, 1987. Avian Physiology of Industrial Poultry Farms in Ethiopia. pp.114-117. Proceedings of the First National Livestock Improvement Conference 11-13 Feb. 1987. Addis Ababa, Ethiopia.

5. BPEDORS, 2000. Physical and socio economical profile of 180 District of Oromia Region. Bureau of Planning and Economic Development of Oromia Regional state, Physical planning Development. Finfinnee, Ethiopia. 248-251p.

6. Bush, J., 2006. The threat of Avian Flu: predicted impacts on rural livelihoods in SNNPR (Ethiopia). FAO and MoARD, Addis Ababa.

7. CSA, 2016/17. Agricultural sample survey. Report on livestock and livestock characteristics. The Federal Democratic Republic of Ethiopia, Private Peasant Holdings, Statistical Bulletin 585, Central Statistical Authority (CSA), Addis Ababa, Ethiopia, April 2016/17.

8. Delgado, C., Rosegrant, M., Steinfeld, H., Ehui, S. and Courbois, C., 2001. Livestock to 2020: the next food revolution. Outlook on Agriculture, 30(1), pp.27-29.

9. Demeke, S., 2004. Egg production performance of local and White Leghorn hens under intensive and rural household conditions in Ethiopia. Livestock Research for Rural Development, <bi $>16</ \mathrm{bi}>(2)$, p.2004.

10. DZARC (Debrezeit Agricultural Research Center). 2012. Annual Research Report 2012/13, Ethiopian Institute Agricultural Research, Debre Zeit, Ethiopia.

11. Ensminger, M. E., J. E. Oldfield and W. W. Herneman, 1990.Feeds and Feeding.2nd ed. Ensiminger Publishing Company, United State, California. $1544 p$.

12. FAO (Food and Agriculture Organization of the United Nations) data, 2005. Rome, Italy.

13. Feltwell, R., 2011. Small-Scale Poultry Keeping: A Guide to Free-Range Poultry Production. Faber \& Faber

14. Gebreselassie G, R. Meseret, Z. Mulalem, H. Hailay, B. Minister and B. Gebru, 2015. Comparative production performance evaluation of exotic and indigenous chickens under farmer's management practice in Tigray. Scientific Journal of Animal Science<bi>4(12</bi>), 181-186 ISSN 2322-1704 doi: 10.14196/sjas. v4i12.2045.

15. Gomez, K.A. and Gomez, A.A., 1984. Statistical procedures for agricultural research. John Wiley \& Sons.

16. Grobbelaar, J.A.N., Sutherland, B. and Molalakgotla, N.M., 2010.Egg production potentials of certain indigenouschicken breeds from South Africa. Animal Genetic Resources/Resources génétiquesanimales/Recursosgenéticosanimales,

17. Hocking, P.M., Bain, M., Channing, C.E., Fleming, R. and Wilson, S., 2003. Genetic variation for egg production, egg quality and bone strength in selected and traditional breeds of laying fowl. British Poultry Science, 44(3), pp.365-373. 
18. Hunton, P., 1995. Egg production, processing and marketing. World Poultry Science, Elsevier, Tokyo, pp.457-480.

19. Jacob, J., Wilson, H., Miles, R., Butcher, G. and Mather, B., 1998. Factors Affecting Egg Production in Backyard Chicken fact sheet PS-35, Institute of Food and Agricultural Sciences, University of Florida. Original publication date April 1998. Reviewed March, 2011. Visit the EDIS website at http://edis.ifas.ufl.edu.

20. Kasa Biratu and Saba Haile., 2016. Demonstration and Performance Evaluation of "Potchefstroom Koekoek" Chicken Package at Jimma Zone, South Western Ethiopia. Ethiopian Institute of Agricultural Research, Jimma Agricultural Research Center, P.O.Box 192, Jimma, Ethiopia. Journal of Biology, Agriculture and Health care, Vol.6, No.15, 2016.

21. Khawaja, T., Khan, S.H., Mukhtar, N., Ali, M.A., Ahmed, T. and Ghafar, A., 2012.Comparative study of growth performance, egg production, egg characteristics and haemato-biochemical parameters of Desi, Fayoumi and Rhode Island Red chicken. Journal of applied animal research, 4O(4),pp.273-283.

22. Layer management program Lohmann Brown. Lohmann Tierzucht G.M.B.H.,Cuxhaven, Germany, 2000.

23. Luiting, P., 1990. Genetic variation of energy partitioning in laying hens: causes of variation in residual feed consumption. World's Poultry Science Journal, 46(2), pp.133-152.

24. Montgomery, D.C., 2001. Design and Analysis of Experiments, John Wiley \& Sons.New York, pp.6465.

25. Motiang, I.B., 2013. Evaluation of different chicken layer breeds for use in integrated aquaculturepoultry production systems in Gauteng, South Africa (Doctoral dissertation).

26. North, M.O., 1984. Pages 690-694 in Commercial Chicken Production Manual. AVI Publ. Co. Inc., Westport, CT.

27. Singh, R., Cheng, K.M. and Silversides, F.G., 2009. Production performance and egg quality of four strains of laying hens kept in conventional cages and floor pens. Poultry science, 88(2), pp.256-264.

28. Silversides, F.G. and Scott, T.A., 2001. Effect of storage and layer age on quality of eggs from two lines of hens.Poultry Science, 80(8), pp.1240-1245.

29. Tadelle, D., Million, T., Alemu, Y. and Peters, K., 2003b. Village chicken production systems in Ethiopia: 1. Flock characteristics and performance; Lives. Res. for Rural Dev. $<\mathrm{bi}>15</ \mathrm{bi}>(1)$. Retrieved May 26, 2012, from http://www.Irrd.org//rrd15/1/tadea151.htm.

30. Tadelle, D., Million, T., Alemu, Y. and Peters, K., 2003c. Village chicken production systems in Ethiopia: 2. Use patterns and performance valuation and chicken products and socio-economic functionsof chicken.Lives. Res. for Rural Dev. 15 (1).http://www.Irrd.org/lrrd15/1/tadeb151.htm

31. Tadesse, D.T., 2012. Management practices, productive performances and egg quality traits of exotic chickens under village production system in East Shewa, Ethiopia. MSc thesis. Debre Zeit, Ethiopia: Addis Ababa University.

32. Teketel Forsido, 1986. Studies on the Meat Production Potential of Some Local Strains of Chickens in Ethiopia. Ph.D Thesis, J. L. Universty of Giessen, Germany. 
33. Tulin C, and Ahmet K, 2009. Comparison of village eggs and commercial eggs in terms of quality. J. Anim. Vet. Adv. 8:2542-2545.

Figures

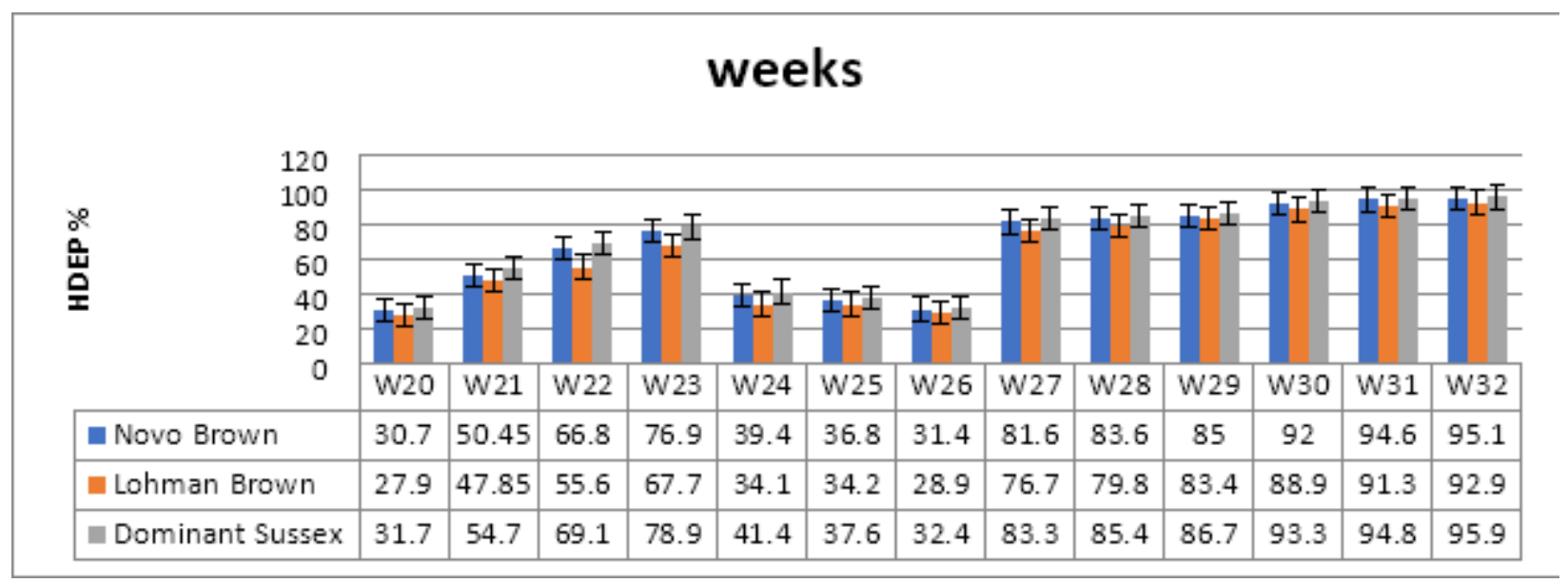

Figure 1

Peak hen day egg production performance of layers 